STRUCTURAL CHEMISTRY

ISSN 2053-2296

Received 12 December 2018

Accepted 25 January 2019

Edited by D. S. Yufit, University of Durham, England

Keywords: J147; DFT calculations; NMR; crystal structure; Alzheimer's disease; GIAO calculations; anti-aging agent.

CCDC reference: 1869097

Supporting information: this article has supporting information at journals.iucr.org/C

\title{
The structure of the anti-aging agent J147 used for treating Alzheimer's disease
}

\author{
Guy J. Clarkson, ${ }^{\mathrm{a}}$ M. Ángeles Farrán, ${ }^{\mathrm{b} *}$ Rosa M. Claramunt, ${ }^{\mathrm{b} *}$ Ibon Alkorta ${ }^{\mathrm{c}}$ and \\ José Elguero ${ }^{c}$
}

\begin{abstract}
${ }^{\mathbf{a}}$ Department of Chemistry, University of Warwick, Coventry CV4 7AL, England, ${ }^{\mathbf{b}}$ Departamento de Química Orgánica y Bio-Orgánica, Facultad de Ciencias, Universidad Nacional de Educación a Distancia, Senda del Rey 9, E-28040 Madrid, Spain, and 'Instituto de Química Médica, Centro de Química Orgánica Manuel Lora-Tamayo, CSIC, Juan de la Cierva 3, E-28006 Madrid, Spain. *Correspondence e-mail: afarran@ccia.uned.es, rclaramunt@ccia.uned.es
\end{abstract}

The molecular structure of the anti-aging agent $\mathbf{J 1 4 7}$ [systematic name: $(E)-N$ (2,4-dimethylphenyl)-2,2,2-trifluoro- $N$ '-(3-methoxybenzylidene)acetohydrazide], $\mathrm{C}_{18} \mathrm{H}_{17} \mathrm{~F}_{3} \mathrm{~N}_{2} \mathrm{O}_{2}$, has been determined at $150 \mathrm{~K}$. The crystal structure corresponds to the minimum-energy conformation in the gas phase calculated by density functional theory (DFT). 15 other conformations have been calculated and compared with the minimum, denoted 1111. NMR spectroscopic data have been obtained and compared with those from Gauge Independent Atomic Orbital (GIAO) calculations. DFT calculations allow the reduction of the 16 possible rotamers to the four most stable (i.e. 1111, 1112, 1121 and 1222); in addition, the calculated barriers connecting these minima are low enough to permit their interconversion. Comparison of the NMR spectroscopic results, both experimental and calculated, point to the $\mathbf{1 1 2 1}$ isomer being present in chloroform solution.

\section{Introduction}

In a recent publication (Farrán et al., 2018b), we used the structure of $\mathbf{J 1 4 7}$ to design a series of 5- $\mathrm{CF}_{3}-1 \mathrm{H}$-triazoles that were afterwards tested as neuroprotective agents (Farrán et al., 2018a). The crystal structure of $\mathbf{J 1 4 7}$ has been reported previously, however, it has not yet been deposited in the Cambridge Structural Database (CSD, Version 5.39, updated August 2018; Groom et al., 2016; checked on September 21, 2018). To the best of our knowledge, the only information on the solid-state structure of $\mathbf{J 1 4 7}$ is the low-quality black-andwhite picture shown in Fig. 1 (Chen et al., 2011).

To gain further insight into the conformational preferences of $\mathbf{J 1 4 7}$, one of the most promising molecules both for treating Alzheimer's disease and for preventing neurological problems associated with aging (Prior et al., 2014; Daugherty et al., 2017,

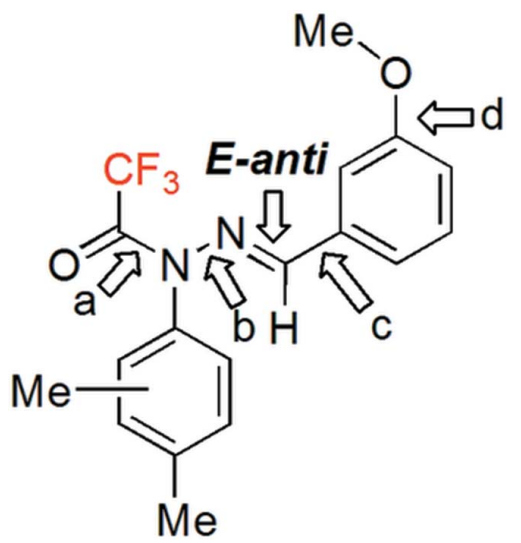

(C) 2019 International Union of Crystallography
2018; Goldberg et al., 2018), we carried out a computational analysis, a solution NMR spectroscopic study and determined the solid-state crystal structure.

\section{Experimental}

\subsection{Synthesis}

$\mathbf{J 1 4 7}$ was prepared in two steps using a procedure modified from Wang et al. (2013), as depicted in Scheme 1.

2.1.1. Preparation of 1-(2,4-dimethylphenyl)-2-(3-methoxybenzylidene)hydrazine, 1. (2,4-Dimethylphenyl)hydrazine hydrochloride ( $951 \mathrm{mg}, 5.51 \mathrm{mmol}$ ) was added to a solution of sodium acetate $(452 \mathrm{mg}, 5.51 \mathrm{mmol})$ in water $(5 \mathrm{ml})$. A solution of 3-methoxybenzaldehyde $(500 \mathrm{mg}, 3.67 \mathrm{mmol})$ in EtOH 
$(3 \mathrm{ml})$ was then added slowly over a period of $5 \mathrm{~min}$. The reaction mixture was heated to $100{ }^{\circ} \mathrm{C}$ and kept stirring for an additional $20 \mathrm{~min}$ until the disappearance of the starting materials monitored by thin-layer chromatography. The mixture was then cooled to $0{ }^{\circ} \mathrm{C}$ in an ice bath and a sticky orange oil precipitated. The remaining liquid fraction was decanted from the residue and washed with cold water. After drying under vacuum, the residue was used in the next step without further purification.

${ }^{1} \mathrm{H}$ NMR (400 MHz, $\left.\mathrm{CDCl}_{3}\right): \delta 7.74\left(1 \mathrm{H}, s, \mathrm{H}-3^{\prime}\right), 7.45(1 \mathrm{H}$, $\left.d,{ }^{3} J=8.2 \mathrm{~Hz}, \mathrm{H}-5^{\prime}\right), 7.31-7.25\left[2 \mathrm{H}, m, \mathrm{H}-5^{\prime \prime}, \mathrm{H}-6(\mathrm{C}=\mathrm{N})\right], 7.20$ $\left(1 \mathrm{H}, d t,{ }^{3} J=7.8,{ }^{4} J=1.3 \mathrm{~Hz}, \mathrm{H}-4^{\prime \prime}\right), 7.03\left(1 \mathrm{H}, d d,{ }^{3} J=8.2\right.$, $\left.2.1 \mathrm{~Hz}, \mathrm{H}-6^{\prime}\right), 6.93-6.91\left(1 \mathrm{H}, m, \mathrm{H}-2^{\prime \prime}\right), 6.86(1 \mathrm{H}, d d d, J=8.1$, 2.7, $\left.1.1 \mathrm{~Hz}, \mathrm{H}-6^{\prime \prime}\right), 3.87$ (3H, s, $\left.\mathrm{OCH}_{3}, \mathrm{H}-15\right), 2.29\left(3 \mathrm{H}, s, \mathrm{CH}_{3}\right.$, $\mathrm{H}-12), 2.22$ (3H, $\left.s, \mathrm{CH}_{3}, \mathrm{H}-10\right) .{ }^{13} \mathrm{C} \mathrm{NMR}\left(101 \mathrm{MHz}, \mathrm{CDCl}_{3}\right): \delta$ $159.8\left(\mathrm{C}-3^{\prime \prime}\right), 140.2\left(\mathrm{C}-4^{\prime}\right), 137.5\left(\mathrm{C}-3^{\prime}\right), 136.9\left(\mathrm{C}-1^{\prime \prime}\right), 131.1$ $\left.\left(\mathrm{C}-2^{\prime}\right), 129.5(\mathrm{C} 6, \mathrm{C}=\mathrm{N})\right], 129.2\left(\mathrm{C}-2^{\prime}\right), 127.7\left(\mathrm{C}-6^{\prime}\right), 120.4$ $\left(\mathrm{C}-1^{\prime}\right), 119.2\left(\mathrm{C}-4^{\prime \prime}\right), 114.5\left(\mathrm{C}-6^{\prime \prime}\right), 113.2\left(\mathrm{C}-3^{\prime}\right), 110.5\left(\mathrm{C}-5^{\prime \prime}\right)$, 55.3 (C-14, OMe), 20.5 (C-10), 17.0 (C-9).<smiles>COc1cccc(C=O)c1</smiles>

\section{$\mathrm{AcONa}$} $\mathrm{EtOH} / \mathrm{H}_{2} \mathrm{O}$<smiles>C=NN(C(=O)C(F)(F)F)c1ccc(C)cc1C</smiles>
J147<smiles>COC</smiles><smiles>COc1ccccc1</smiles>

Table 1

Experimental details.

\begin{tabular}{|c|c|}
\hline \multicolumn{2}{|l|}{ Crystal data } \\
\hline Chemical formula & $\mathrm{C}_{18} \mathrm{H}_{17} \mathrm{~F}_{3} \mathrm{~N}_{2} \mathrm{O}_{2}$ \\
\hline$M_{\mathrm{r}}$ & 350.33 \\
\hline Crystal system, space group & Monoclinic, $P 2_{1} / c$ \\
\hline Temperature $(\mathrm{K})$ & 150 \\
\hline$a, b, c(\AA)$ & 15.0494 (3), 14.2369 (3), 7.9898 (2) \\
\hline$\beta\left({ }^{\circ}\right)$ & $99.025(2)$ \\
\hline$V\left(\AA^{3}\right)$ & $1690.68(7)$ \\
\hline$Z$ & 4 \\
\hline Radiation type & $\mathrm{Cu} K \alpha$ \\
\hline$\mu\left(\mathrm{mm}^{-1}\right)$ & 0.97 \\
\hline Crystal size $(\mathrm{mm})$ & $0.2 \times 0.08 \times 0.02$ \\
\hline \multicolumn{2}{|l|}{ Data collection } \\
\hline Diffractometer & $\begin{array}{l}\text { Rigaku Oxford Diffraction Super- } \\
\text { Nova diffractometer with a dual } \\
\text { source }(\mathrm{Cu} \text { at zero) equipped } \\
\text { with an AtlasS2 CCD area } \\
\text { detector }\end{array}$ \\
\hline Absorption correction & $\begin{array}{l}\text { Multi-scan (CrysAlis PRO; Rigaku } \\
\text { OD, 2018) }\end{array}$ \\
\hline$T_{\min }, T_{\max }$ & $0.792,1.000$ \\
\hline $\begin{array}{l}\text { No. of measured, independent and } \\
\text { observed }[I>2 \sigma(I)] \text { reflections }\end{array}$ & $5945,5945,4685$ \\
\hline $\begin{array}{l}R_{\text {int }} \\
(\sin \theta / \lambda)_{\max }\left(\AA^{-1}\right)\end{array}$ & $\begin{array}{l}0.037 \text { (for all HKLF5 reflections) } \\
0.622\end{array}$ \\
\hline \multicolumn{2}{|l|}{ Refinement } \\
\hline$R\left[F^{2}>2 \sigma\left(F^{2}\right)\right], w R\left(F^{2}\right), S$ & $0.035,0.096,0.99$ \\
\hline No. of reflections & 5945 \\
\hline No. of parameters & 230 \\
\hline H-atom treatment & H-atom parameters constrained \\
\hline$\Delta \rho_{\max }, \Delta \rho_{\min }\left(\mathrm{e} \AA^{-3}\right)$ & $0.21,-0.23$ \\
\hline
\end{tabular}

Computer programs: CrysAlis PRO (Rigaku OD, 2018), SHELXT (Sheldrick, 2015a), SHELXL2018 (Sheldrick, 2015b) and OLEX2 (Dolomanov et al., 2009).

1-(2,4-dimethylphenyl)-2-(3-methoxybenzylidene)hydrazine (500 mg, $1.97 \mathrm{mmol})$ and $\mathrm{Et}_{3} \mathrm{~N}(0.33 \mathrm{ml}, 2.36 \mathrm{mmol})$ in $\mathrm{CH}_{2} \mathrm{Cl}_{2}$ $(5 \mathrm{ml})$ was placed in a round-bottomed flask and cooled to $0{ }^{\circ} \mathrm{C}$ in an ice bath, after which trifluoroacetic anhydride $(0.33 \mathrm{ml}, 2.36 \mathrm{mmol})$ was added dropwise under a nitrogen atmosphere. The reaction mixture was stirred at this temperature for $1.5 \mathrm{~h}$. After the mixture had been concentrated under vacuum, the residue was purified by column

2.1.2. (E)-N-(2,4-Dimethylphenyl)-2,2,2-trifluoro- $N^{\prime}$-(3methoxybenzylidene)acetohydrazide, J147. A solution of
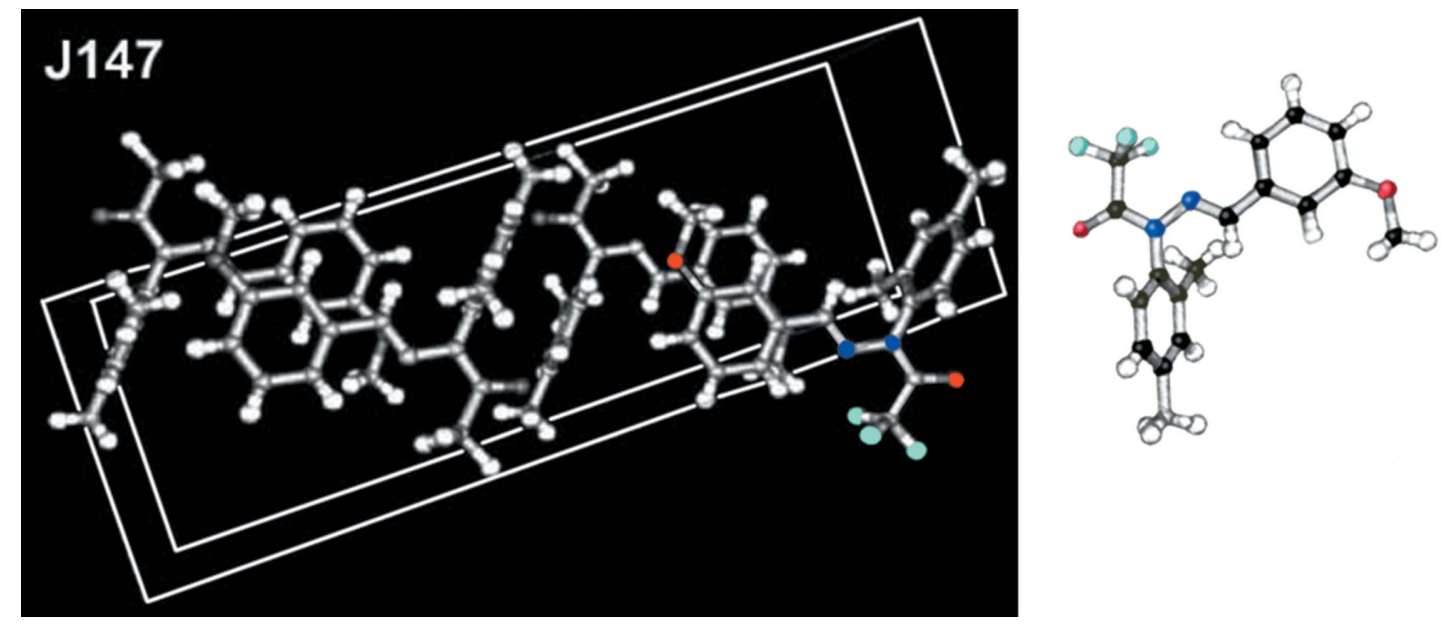

Figure 1

(Left) Picture taken from Chen et al. (2011) illustrating their crystal structure determination of J147. (Right) An individual molecule of J147 (Farrán et $a l ., 2018 b$ ). The colours have been added by the present authors. 
chromatography using a mixture of acetone/hexanes $(1: 10 v / v)$ as eluent to afford $\mathbf{J 1 4 7}$ (yield $571 \mathrm{mg}, 83 \%$ ) as a pale-pink oil. A second column was needed to remove slight impurities and the compound was then recrystallized from ethanol/water at $-4{ }^{\circ} \mathrm{C}$. White crystals suitable for single-crystal X-ray diffraction analysis were obtained.

${ }^{1} \mathrm{H}$ NMR $\left(400 \mathrm{MHz}, \mathrm{CDCl}_{3}\right): \delta 7.29\left(1 \mathrm{H}, d,{ }^{3} J=7.9 \mathrm{~Hz}\right.$, $\left.\mathrm{H}-5^{\prime \prime}\right), 7.27-7.23\left[3 \mathrm{H}, m, \mathrm{H}-2^{\prime \prime}, \mathrm{H}-3^{\prime}, \mathrm{H}-6(\mathrm{C}=\mathrm{N})\right], 7.21(1 \mathrm{H}, d$, $\left.J=7.9 \mathrm{~Hz}, \mathrm{H}-5^{\prime}\right), 7.12\left(1 \mathrm{H}, d,{ }^{3} J=7.2 \mathrm{~Hz}, \mathrm{H}-4^{\prime \prime}\right), 7.05(1 \mathrm{H}, d$, $\left.{ }^{3} J=7.9 \mathrm{~Hz}, \mathrm{H}-6^{\prime}\right), 6.95\left(d d d, J=8.3,2.6,1.0 \mathrm{~Hz}, 1 \mathrm{H}, \mathrm{H}-6^{\prime \prime}\right), 3.83$ $\left(s, 3 \mathrm{H}, \mathrm{OCH}_{3}, \mathrm{H}-15\right), 2.42\left(s, 3 \mathrm{H}, \mathrm{CH}_{3}, \mathrm{H}-12\right), 2.09\left(s, 3 \mathrm{H}, \mathrm{CH}_{3}\right.$, $\mathrm{H}-10) .{ }^{13} \mathrm{C}$ NMR (101 MHz, $\left.\mathrm{CDCl}_{3}\right): \delta 159.9\left(\mathrm{C}-3^{\prime \prime}\right), 157.3(d$, $\left.\mathrm{COCF}_{3},{ }^{3} J_{\mathrm{F}}=36 \mathrm{~Hz}\right), 143.9(\mathrm{C} 6, \mathrm{C}=\mathrm{N}), 140.9\left(\mathrm{C}-4^{\prime}\right), 136.2$ $\left(\mathrm{C}-2^{\prime}\right), 134.7\left(\mathrm{C}-1^{\prime \prime}\right), 132.6\left(\mathrm{C}-3^{\prime}\right), 129.8\left(\mathrm{C}-5^{\prime \prime}\right), 129.6\left(\mathrm{C}-1^{\prime}\right)$, $128.7\left(\mathrm{C}-5^{\prime}\right), 128.5\left(\mathrm{C}-6^{\prime}\right), 121.2\left(\mathrm{C}-1^{\prime \prime}\right), 117.1\left(\mathrm{C}-6^{\prime \prime}\right), 117.2[q$, $\left.\left(\mathrm{COCF}_{3}\right){ }^{2} J_{\mathrm{F}}=287 \mathrm{~Hz}\right], 111.7\left(\mathrm{C}-2^{\prime \prime}\right), 55.3(\mathrm{C}-14, \mathrm{OMe}), 21.3$ (C-10), $17.0(\mathrm{C}-9) .{ }^{19} \mathrm{~F}\left(379.5 \mathrm{MHz}, \mathrm{CDCl}_{3}\right): \delta-69.5$.

\subsection{Crystallography}

Crystal data, data collection and structure refinement details are summarized in Table 1. Single crystals of $\mathbf{J 1 4 7}$ were grown from water-ethanol. A crystal suitable for X-ray structure analysis was selected and mounted on a glass fiber with Fomblin oil.

The harvesting of the spots and integration was performed with the twin module in the CrysAlis PRO software package (Agilent, 2014). The twin ratio refined to $75: 25$ with the twin components related by a $180^{\circ}$ rotation around the vector (100) in direct space. $\mathrm{H}$ atoms were given isotropic displacement parameter equal to 1.2 (or 1.5 for methyl $\mathrm{H}$ atoms) times the equivalent isotropic displacement parameter of the $\mathrm{C}$ atom to which they are attached.

\subsection{NMR experiments}

NMR spectra were recorded on a Bruker DRX 400 (9.4 Tesla, $400.13 \mathrm{MHz}$ for ${ }^{1} \mathrm{H}, 100.61 \mathrm{MHz}$ for ${ }^{13} \mathrm{C}$ and $40.54 \mathrm{MHz}$ for ${ }^{15} \mathrm{~N}$ ), using a $5 \mathrm{~mm}$ inverse-detection $\mathrm{H}-\mathrm{X}$ probe equipped with a z-gradient coil, at $300 \mathrm{~K}$. Chemical shifts ( $\delta$ in ppm) are given from the internal solvent; $\mathrm{CDCl}_{3}=7.26$ and 77.0 for ${ }^{1} \mathrm{H}$ and ${ }^{13} \mathrm{C}$, respectively, were used as external references. Signals were characterized as $s$ (singlet), $d$ (doublet), $t$ (triplet), $q$ (quartet) and $m$ (multiplet), and $J$ couplings are given in $\mathrm{Hz}$.

Typical parameters for ${ }^{1} \mathrm{H}$ NMR spectra were a spectral width of $4800 \mathrm{~Hz}$ and a pulse width of $9.5 \mathrm{~ms}$ at an attenuation level of $0 \mathrm{~dB}$. Typical parameters for ${ }^{13} \mathrm{C}$ NMR spectra were a spectral width of $21 \mathrm{kHz}$, a pulse width of $12.5 \mathrm{~ms}$ at an attenuation level of $-6 \mathrm{~dB}$ and a relaxation delay of $2 \mathrm{~s}$. WALTZ-16 was used for broadband proton decoupling; the FIDS (free induction decays) were multiplied by an exponential weighting $(\mathrm{lb}=1 \mathrm{~Hz})$ before Fourier transformation.

Inverse proton-detected heteronuclear shift correlation spectra, $\left({ }^{1} \mathrm{H}-{ }^{13} \mathrm{C}\right)$ gs-HMQC and $\left({ }^{1} \mathrm{H}_{-}{ }^{13} \mathrm{C}\right)$ gs-HMBC, were acquired and processed using standard Bruker NMR software in nonphase-sensitive mode. Gradient selection was achieved through a $5 \%$ sine truncated shaped pulse gradient of $1 \mathrm{~ms}$.
Table 2

Calculated and experimental chemical shifts $(\delta, \mathrm{ppm})$ in $\mathrm{CDCl}_{3}$ (note that the NMR atom numbering is different from the crystallographic atom numbering).

\begin{tabular}{|c|c|c|c|c|c|c|}
\hline $\begin{array}{l}\text { NMR } \\
\text { atoms }\end{array}$ & $\begin{array}{l}\text { X-ray } \\
\text { atoms }\end{array}$ & 1111 & 1112 & 1121 & 1122 & Experimental \\
\hline $\mathrm{C} 1(\mathrm{C}=\mathrm{O})$ & $\mathrm{C} 2$ & 155.8 & 156.2 & 156.0 & 156.0 & $157.3(q),{ }^{2} J_{\mathrm{F}}=36 \mathrm{~Hz}$ \\
\hline $\mathrm{C} 2\left(\mathrm{CF}_{3}\right)$ & $\mathrm{C} 1$ & 121.2 & 121.1 & 121.1 & 121.1 & $117.2(q),{ }^{1} J_{\mathrm{F}}=287 \mathrm{~Hz}$ \\
\hline $\mathrm{C} 6(\mathrm{C}=\mathrm{N})$ & $\mathrm{C} 5$ & 141.2 & 140.8 & 141.1 & 141.1 & 143.9 \\
\hline $\mathrm{H} 8(\mathrm{C} 6-\mathrm{H})$ & H5 & 7.02 & 6.97 & 6.94 & 6.95 & 7.26 (under the solvent) \\
\hline $\mathrm{C}^{\prime}$ & $\mathrm{C} 12$ & 132.1 & 132.2 & 132.6 & 132.4 & 129.6 \\
\hline $\mathrm{C}^{\prime}$ & $\mathrm{C} 13$ & 140.1 & 140.1 & 140.4 & 140.2 & 136.2 \\
\hline $\mathrm{C} 3^{\prime}$ & $\mathrm{C} 14$ & 131.5 & 131.6 & 131.6 & 131.7 & 132.6 \\
\hline $\mathrm{C} 4^{\prime}$ & $\mathrm{C} 15$ & 142.4 & 142.3 & 142.3 & 142.4 & 140.9 \\
\hline $\mathrm{C}^{\prime}$ & $\mathrm{C} 16$ & 127.6 & 127.6 & 127.5 & 127.6 & 128.7 \\
\hline $\mathrm{C}^{\prime}$ & $\mathrm{C} 17$ & 129.3 & 129.5 & 129.6 & 129.5 & 128.5 \\
\hline $\mathrm{C1}^{\prime \prime}$ & $\mathrm{C} 6$ & 136.1 & 136.2 & 135.8 & 136.4 & 134.7 \\
\hline $\mathrm{C} 2^{\prime \prime}$ & $\mathrm{C} 7$ & 104.7 & 115.0 & 110.0 & 120.4 & 111.7 \\
\hline $\mathrm{C}^{\prime \prime}$ & $\mathrm{C} 8$ & 161.4 & 160.7 & 160.4 & 160.4 & 159.9 \\
\hline $\mathrm{C} 4^{\prime \prime}$ & C9 & 121.1 & 109.7 & 119.7 & 108.6 & 121.2 \\
\hline $\mathrm{C} 5^{\prime \prime}$ & $\mathrm{C} 10$ & 128.6 & 128.7 & 129.8 & 129.7 & 129.8 \\
\hline $\mathrm{C}^{\prime \prime}$ & $\mathrm{C} 11$ & 122.6 & 122.1 & 118.1 & 117.7 & 117.1 \\
\hline C9 $\left(\mathrm{Me}-2^{\prime}\right)$ & $\mathrm{C} 13 a$ & 17.9 & 17.9 & 17.9 & 17.9 & 17.0 \\
\hline H10 (Me-2') & $\mathrm{H} 13 a$ & 2.03 & 2.03 & 2.04 & 2.03 & 2.09 \\
\hline C11 (Me-4') & $\mathrm{C} 15 a$ & 21.2 & 21.2 & 21.2 & 21.2 & 21.3 \\
\hline H12 (Me-4') & $\mathrm{H} 15 a$ & 2.40 & 2.41 & 2.39 & 2.40 & 2.42 \\
\hline $\mathrm{C} 14(\mathrm{O}-\mathrm{Me})$ & $\mathrm{C} 18$ & 53.0 & 52.6 & 52.2 & 52.5 & 55.2 \\
\hline $\mathrm{H} 15(\mathrm{O}-\mathrm{Me})$ & H18 & 3.78 & 3.69 & 3.54 & 3.63 & 3.83 \\
\hline $\mathrm{H} 3^{\prime}$ & H14 & 7.21 & 7.20 & 7.24 & 7.22 & 7.24 \\
\hline $\mathrm{H} 5^{\prime}$ & H16 & 7.17 & 7.18 & 7.17 & 7.19 & 7.21 \\
\hline $\mathrm{H} 6^{\prime}$ & H17 & 6.96 & 6.97 & 6.98 & 6.98 & 7.03 \\
\hline $\mathrm{H} 2^{\prime \prime}$ & $\mathrm{H} 7$ & 7.60 & 7.98 & 6.13 & 6.57 & 7.27 \\
\hline $\mathrm{H} 4^{\prime \prime}$ & H9 & 6.99 & 6.56 & 6.96 & 6.51 & 7.12 \\
\hline $\mathrm{H} 5^{\prime \prime}$ & H10 & 7.09 & 7.12 & 7.27 & 7.27 & 7.29 \\
\hline $\mathrm{H} 6^{\prime \prime}$ & H11 & 6.52 & 6.49 & 7.99 & 7.93 & 6.95 \\
\hline
\end{tabular}

Selected parameters for $\left({ }^{1} \mathrm{H}_{-}{ }^{13} \mathrm{C}\right)$ gs-HMQC and $\left({ }^{1} \mathrm{H}_{-}{ }^{13} \mathrm{C}\right)$ gs-HMBC spectra were a spectral width of $4800 \mathrm{~Hz}$ for ${ }^{1} \mathrm{H}$ and $20.5 \mathrm{kHz}$ for ${ }^{13} \mathrm{C}, 1024 \times 256$ data set, number of scans $=2$ (gsHMQC) or 4 (gs-HMBC) and a relaxation delay of $1 \mathrm{~s}$. The FIDs were processed using zero filling in the F1 domain and a sine-bell window function in both dimensions was applied prior to Fourier transformation. In the gs-HMQC experiments, GARP modulation of ${ }^{13} \mathrm{C}$ was used for decoupling.

${ }^{19} \mathrm{~F}$ NMR spectra were recorded on the same spectrometer $\left(376.50 \mathrm{MHz}\right.$ for ${ }^{19} \mathrm{~F}$ ), using a $5 \mathrm{~mm}$ QNP direct-detection probe head equipped with a z-gradient coil, at $300 \mathrm{~K}$. Chemical shifts ( $\delta$ in ppm) are given from $\mathrm{CFCl}_{3}$ as external reference [one drop of $\mathrm{CFCl}_{3}$ in $0.6 \mathrm{ml} \mathrm{CDCl}_{3}(0.00)$ ]. Typical parameters for ${ }^{19} \mathrm{~F}$ NMR spectra were a spectral width of $55 \mathrm{kHz}$, a pulse width of $13.75 \mathrm{~ms}$ at an attenuation level of $-6 \mathrm{~dB}$ and a relaxation delay of $1 \mathrm{~s}$. WALTZ-16 was used for broadband proton decoupling; ${ }^{19} \mathrm{~F}\left\{{ }^{1} \mathrm{H}\right\}$ and the FIDs were multiplied by an exponential weighting $(\mathrm{lb}=1 \mathrm{~Hz})$ before Fourier transformation.

\subsection{Computational details}

B3LYP/6-311++G(d,p) calculations (Ditchfield et al., 1971; Frisch et al., 1984) were carried out using GAUSSIAN16 (Frisch et al., 2016). Frequency calculations show that all the reported structures are minima (number of imaginary frequencies $=0$ ). Theoretical calculations of the absolute shieldings $(\sigma, \mathrm{ppm})$ and their transformation into chemical 
Figure 2

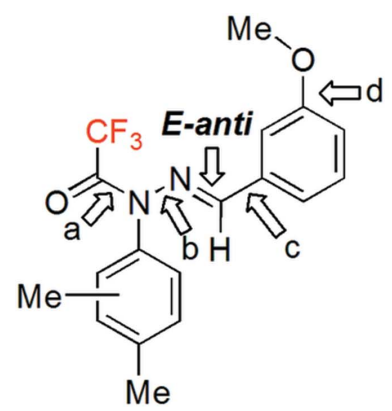

This structure of configuration $E$-anti is the reference orientation for analyzing the $a, b, c$ and d rotations

A $180^{\circ}$ rotation about one of these four bonds will transform 1 in 2, from 1111 (0000) to 2222 (180180180180)

The $0^{\circ}$ and $180^{\circ}$ angles are the starting values before geometrical optimization; afterwards they change approaching in some cases values close to $90^{\circ}$

The structure of the reference starting orientation and the rotatable bond-numbering system.

shifts $(\delta, \mathrm{ppm})$ were carried out at the GIAO/B3LYP/6$311++\mathrm{G}(\mathrm{d}, \mathrm{p})$ level, as described in previous papers (Claramunt et al., 2006; Blanco et al., 2007; Infantes et al., 2018).

\section{Results and discussion}

\subsection{Theoretical exploration of the conformation of J147}

The $E / Z$ configuration about the $\mathrm{C}=\mathrm{N}$ double bond requires high energies, about $150 \mathrm{~kJ} \mathrm{~mol}^{-1}$, to isomerize (Blanco et al. 2009) it and is $E$ in the illustration in Chen et al. (2011), corresponding to the most stable isomer according to calculations. Besides the hydrazone, there are four single bonds that can be rotated, i.e. $\mathbf{a}, \mathbf{b}, \mathbf{c}$ and $\mathbf{d}$, leading to $2^{4}=16$ rotamers (Fig. 2). In the supporting information, the 16 possible rotamers are reported. Rotamer $\mathbf{1 1 1 1}$ was selected as the reference compound because the calculations performed showed that it is the most stable of the 16 rotamers.

B3LYP/6-311++G(d,p) calculations show that the four most stable rotamers are those represented in Fig. 3. The remaining 12 rotamers have energy values ranging from 16 to $38 \mathrm{~kJ} \mathrm{~mol}^{-1}$ higher.

It appears that the previously reported structure corresponds to the 1121 rotamer with an energy $5.1 \mathrm{~kJ} \mathrm{~mol}^{-1}$ higher than for the $\mathbf{1 1 1 1}$ rotamer. However, since the energy difference between these rotamers is relatively small, all of them must co-exist to varying degrees in solution. Four transition states (see supporting information) that connect the four minima were calculated in order to verify their low value and to prove that thermodynamic equilibrium should be reached instantly: $\mathbf{T S}_{\mathbf{1 1 1 1 - 1 1 1 2}}=16.3, \mathbf{T} \mathbf{S}_{\mathbf{1 1 1 1}-\mathbf{1 1 2 1}}=32.3, \mathbf{T S} \mathbf{S 1 1 2 - 1 1 2 2}_{\mathbf{1 1 1}}=27.5$ and $\mathbf{T S}_{\mathbf{1 1 2 1 - 1 1 2 2}}=11.8 \mathrm{~kJ} \mathrm{~mol}^{-1}$ (see Fig. 4).
The 16 relative energies $\left(\mathrm{kJ} \mathrm{mol}^{-1}\right)$ can be analyzed using a presence-absence matrix $\left(0\right.$, angle $=0^{\circ} ; 1$, angle $\left.180^{\circ}\right)$ that is a, b, c and d have the values 0 or 1 for the different $\mathbf{x x x x}$ conformers, for instance, $\mathbf{1 2 2 1}=0110$. Preliminary tests show that these angles are related two-by-two, i.e. $\mathbf{a}$ with $\mathbf{b}$ and $\mathbf{c}$ with d, and adding two cross-terms $(\mathbf{a}-1)(\mathbf{b}-1)$ and $(\mathbf{c}-1)(\mathbf{d}-1)$, we obtain:

$E_{\text {rel }}\left(\mathrm{kJ} \mathrm{mol}^{-1}\right)=(17.0 \pm 0.3)(\mathbf{a}-1)+(33.4 \pm 0.3)(\mathbf{b}-1)+$ $(4.6 \pm 0.3)(\mathbf{c}-1)+(4.7 \pm 0.3)(\mathbf{d}-1)-(29.2 \pm 0.5)[(\mathbf{a}-1)(\mathbf{b}-$ $1)]-(5.5 \pm 0.5)[(\mathbf{c}-1)(\mathbf{d}-1)], n=16, R^{2}=1.000$, r.m.s. $=$ $0.6 \mathrm{~kJ} \mathrm{~mol}^{-1}$.

Rotations about bonds $\mathbf{a}$ and $\mathbf{b}$ decreases the stability (increases the relative energy) by 17.0 and $33.4 \mathrm{~kJ} \mathrm{~mol}^{-1}$, while rotations about the methoxyphenyl ring (c bond) and about the methoxy substituent (d bond) have lesser effects (4.6-4.7 $\left.\mathrm{kJ} \mathrm{mol}^{-1}\right)$. Of both cross-terms, clearly the rotations around bonds a and $\mathbf{b}$ are strongly related, which is apparent from an examination of the structures, where the proximity of the $-\mathrm{CF}_{3}$ and $\mathrm{C}-\mathrm{H}$ groups (structures $\mathbf{1 2 x x}$ ) is strongly disfavoured. Correlation between bonds $\mathbf{c}$ and $\mathbf{d}$ is much weaker $\left(5.5 \mathrm{~kJ} \mathrm{~mol}^{-1}\right)$.

\subsection{Determination of the X-ray structure of $\mathbf{J} 147$}

Crystals were grown from an ethanol/water solution. All crystals examined exhibited twinning; the extent of twinning for each crystal investigated was estimated visually by checking the frames from the pre-experiment and examining the twinned spots. The strongest diffracting sample that appeared to have the least twinning was chosen and the data<smiles>COc1cccc(/C=N/N(C(=O)C(F)(F)F)C2=CI(C)C=C(C)C=C2)c1</smiles>

1111: 0.0<smiles>COc1cccc(/C=N/N(C(=O)C(F)(F)F)C2=IC(C)=CC(C)=I2)c1</smiles>

1112: 4.9<smiles>COc1cccc(/C=N/N(C(=O)C(F)(F)F)C2=C[IH](C)=C(C)C=C2)c1</smiles>

1121: 5.1<smiles>COc1cccc(/C=N/N(C(=O)C(F)(F)F)c2ccc(C)cc2)c1</smiles>

The four most stable predicted rotamers (energy values in $\mathrm{kJ} \mathrm{mol}^{-1}$ ). 


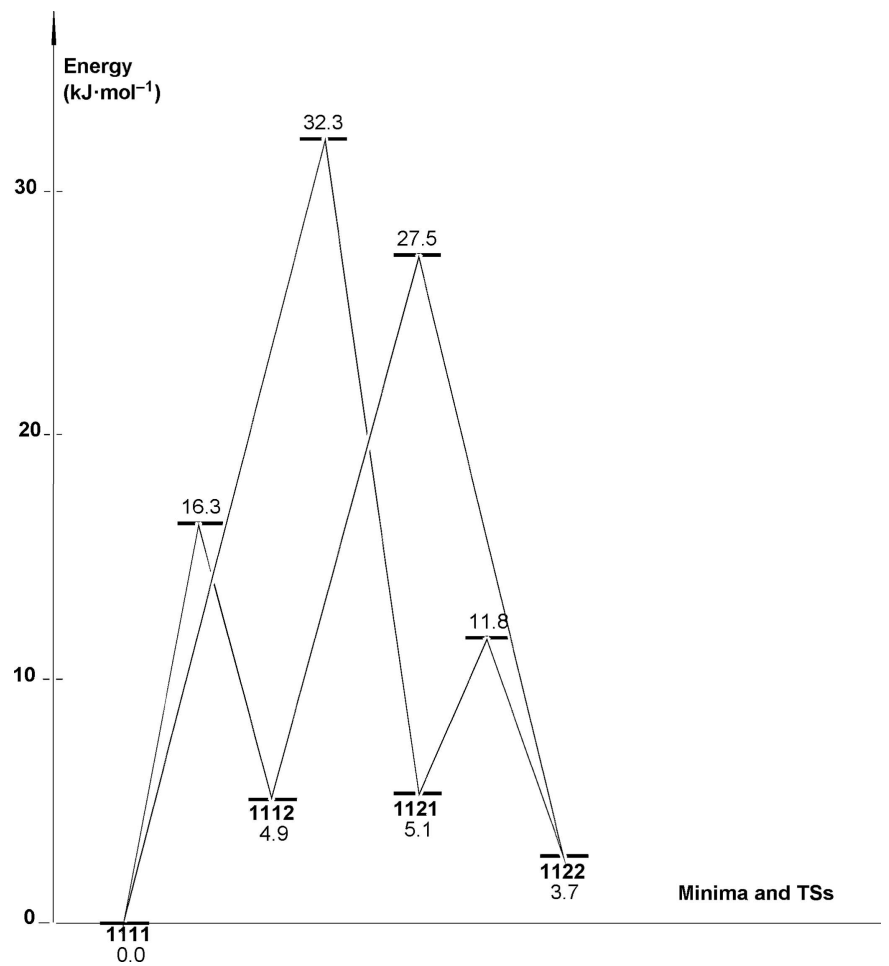

Figure 4

The four most stable minima and the four transition states connecting them.

were recorded for that sample. The asymmetric unit contains one molecule. The twin ratio refined to 75:25 and the two twin components are related by a rotation of $180.0^{\circ}$ around the following vectors: reciprocal space $(h k l)=0.9591-0.0004$ -0.2832 ; direct space $(u v w)=1.0000-0.0000-0.0000$. This orientation observed in the solid state corresponds to the minimum 1111 (Fig. 5).

There are no direction-specific interactions between the molecules in the solid state. $\mathbf{J 1 4 7}$ contains no strong hydrogenbond donors and relatively weak hydrogen-bond acceptors in the form of the $\mathrm{F}$ atoms and the trifluoroacetamide carbonyl $\left[\mathrm{CF}_{3}-\mathrm{C}(=\mathrm{O})-\mathrm{N}\right]$ group. The short contacts between the weak acceptors and the poor $\mathrm{C}-\mathrm{H}$ donors of the aromatic rings and the methyl groups are $>2.6 \AA$ or alternatively between the acceptor and donor atoms are $>3.4 \AA$, indicating no strong interactions. Though some of the aromatic rings are parallel, there is little or no overlap to indicate possible $\pi$-stacking interactions.

\subsection{NMR characterization}

The NMR data for $\mathbf{J 1 4 7}$ in $\mathrm{CDCl}_{3}$ have been reported previously (Chiruta et al., 2013), but not assigned and with some signals not belonging to $\mathbf{J 1 4 7}$. In order to clarify this, we recorded the ${ }^{1} \mathrm{H},{ }^{13} \mathrm{C}$ and ${ }^{19} \mathrm{~F}$ NMR spectra. Experimental chemical shifts, along with those calculated for different rotamers, are shown in Table 2.

The unassigned chemical shifts of $\mathbf{J 1 4 7}$ in $\mathrm{CDCl}_{3}$ (Chiruta et al. 2013) only partially coincide with those we have determined anew in the same solvent and with unambiguous

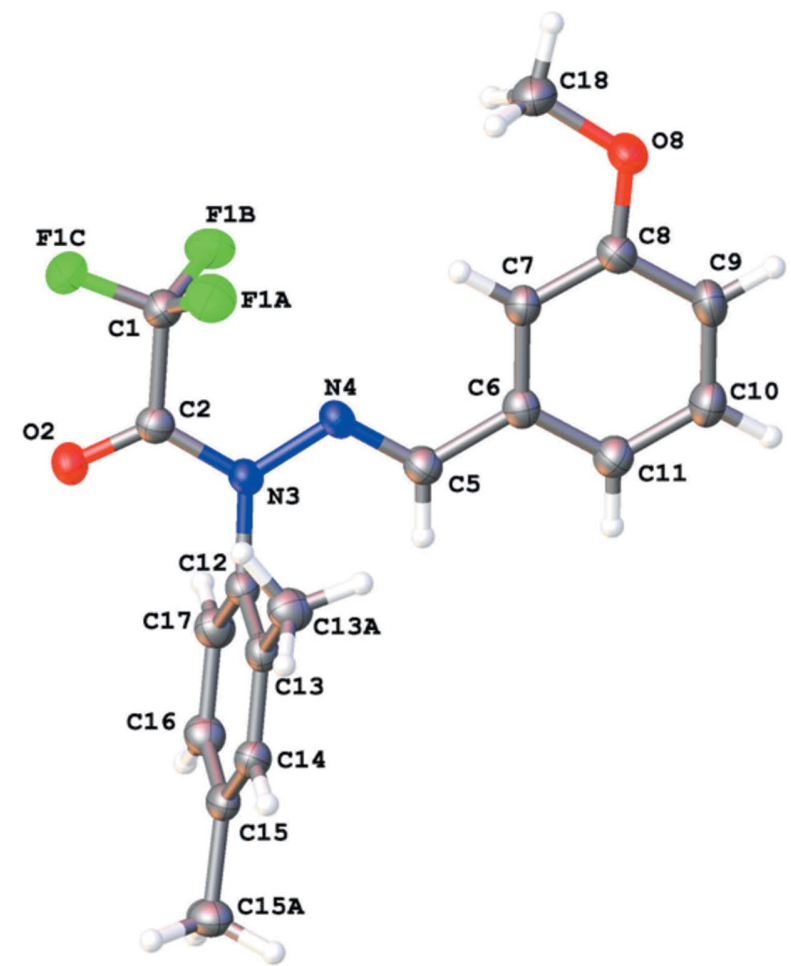

Figure 5

The X-ray structure of $\mathbf{J 1 4 7}$ determined in this article, corresponding to the $\mathbf{1 1 1 1}$ rotamer shown with crystallographic atom numbering.

assignments (Table 2). The linear regressions corresponding to the four isomers are:

Exp. $=(0.2 \pm 0.7)+(0.995 \pm 0.007) *(\mathbf{1 1 1 1}), R^{2}=0.9987$, r.m.s. error $=2.3 \mathrm{ppm}$

Exp. $=(0.3 \pm 0.8)+(0.996 \pm 0.009) *(\mathbf{1 1 1 1}), R^{2}=0.9979$, r.m.s. error $=2.9 \mathrm{ppm}$

Exp. $=(0.2 \pm 0.5)+(0.996 \pm 0.005) *(\mathbf{1 1 2 1}), R^{2}=0.9993$, r.m.s. error $=1.7 \mathrm{ppm}$

Exp. $=(0.3 \pm 1.0)+(0.995 \pm 0.010) *(\mathbf{1 1 2 2}), R^{2}=0.9973$, r.m.s. error $=3.3 \mathrm{ppm}$.

The $\mathbf{1 1 2 1}$ isomer (the previously reported solid-state orientation) appears to be the best candidate for the structure of $\mathbf{J 1 4 7}$ in chloroform solution.

\section{Conclusions}

The orientation depicted in Fig. 1 corresponds to the $\mathbf{1 1 2 1}$ rotamer about bond $\mathbf{c}$ of the $\mathbf{1 1 1 1}$ orientation of the structure determined in this article. In $\mathrm{CDCl}_{3}$ solution, on the other hand, the $\mathbf{1 1 2 1}$ rotamer appears to be predominant. Both results are of much interest for future studies of $\mathbf{J 1 4 7}$ in the solid state (polymorphism) and in solution.

\section{Acknowledgements}

Computer, storage and other resources from the CTI (CSIC) are gratefully acknowledged. 


\section{Funding information}

Funding for this research was provided by: Ministerio de Economía, Industria y Competitividad, Gobierno de España (grant Nos. CTQ2014-56833-R and CTQ2015-63997-C2-2-P); Comunidad Autónoma de Madrid (Spain) (grant No. S2013/ MIT-2841, Fotocarbon).

\section{References}

Agilent (2014). CrysAllis PRO. Agilent Technologies Ltd, Yarnton, Oxfordshire, England.

Blanco, F., Alkorta, I. \& Elguero, J. (2007). Magn. Reson. Chem. 45, 797-800.

Blanco, F., Alkorta, I. \& Elguero, J. (2009). Croat. Chem. Acta, 82, 173-183.

Chen, Q., Prior, M., Dargusch, R., Roberts, A., Riek, R., Eichmann, C., Chiruta, C., Akaishi, T., Abe, K., Maher, P. \& Schubert, D. (2011). PLoS One, 6, e27865.

Chiruta, C., Zhao, Y., Tang, F., Wang, T. \& Schubert, D. (2013). Bioorg. Med. Chem. 21, 2733-2741.

Claramunt, R. M., Cornago, P., Torres, V., Pinilla, E., Torres, M. R., Samat, A., Lokshin, V., Valés, M. \& Elguero, J. (2006). J. Org. Chem. 71, 6881-6891.

Daugherty, D., Goldberg, J., Fischer, W., Dargush, R., Maher, P. A. \& Schubert, D. (2017). Alzheimers Res. Ther. 9, article No. 50.

Daugherty, D. J., Marquez, A., Calcutt, N. A. \& Schubert, D. (2018). Neuropharmacology, 129, 26-35.
Ditchfield, R., Hehre, W. J. \& Pople, J. A. (1971). J. Chem. Phys. 54, 724-728.

Dolomanov, O. V., Bourhis, L. J., Gildea, R. J., Howard, J. A. K. \& Puschmann, H. (2009). J. Appl. Cryst. 42, 339-341.

Farrán, M. A., Bonet, M. A., Claramunt, R. M., Moreno Fernández, C. A., Martínez Casanova, D. \& Lavandera, J. L. (2018a). 18th Meeting of the 'Sociedad Española de Química Terapéutica', Salamanca, Spain, January 23-26, 2018.

Farrán, M. Á., Bonet, M. Á., Claramunt, R. M., Torralba, M. C., Alkorta, I. \& Elguero, J. (2018b). Acta Cryst. C74, 513-522.

Frisch, M. J., Pople, J. A. \& Binkley, J. S. (1984). J. Chem. Phys. 80, 3265-3269.

Frisch, M. J. et al. (2016). GAUSSIAN16. Revision A.03. Gaussian Inc., Wallingford, CT, USA. http://www.gaussian.com

Goldberg, J., Currais, A., Prior, M., Fischer, W., Chiruta, C., Ratliff, E., Daugherty, D., Dargusch, R., Finley, K., Esparza-Moltó, P. B., Cuezva, J. M., Maher, P., Petrascheck, M. \& Schubert, D. (2018). Aging Cell, 17, e12715.

Groom, C. R., Bruno, I. J., Lightfoot, M. P. \& Ward, S. C. (2016). Acta Cryst. B72, 171-179.

Infantes, L., Moreno, J. M., Claramunt, R. M., Sanz, D., Alkorta, I. \& Elguero, J. (2018). Inorg. Chim. Acta, 483, 402-410.

Prior, M., Chiruta, C., Currais, A., Goldberg, J., Ramsey, J., Dargusch, R., Maher, P. A. \& Schubert, D. (2014). ACS Chem. Neurosci. 5, 503-513.

Rigaku OD (2018). CrysAlis PRO. Rigaku Oxford Diffraction Ltd, Yarnton, Oxfordshire, England.

Sheldrick, G. M. (2015). Acta Cryst. A71, 3-8.

Wang, M., Gao, M. \& Zheng, K. H. (2013). Bioorg. Med. Chem. Lett. 23, 524-527. 


\title{
supporting information
}

Acta Cryst. (2019). C75, 271-276 [https://doi.org/10.1107/S205322961900144X]

\section{The structure of the anti-aging agent J147 used for treating Alzheimer's disease}

\author{
Guy J. Clarkson, M. Ángeles Farrán, Rosa M. Claramunt, Ibon Alkorta and José Elguero
}

Computing details

Data collection: CrysAlis PRO (Rigaku OD, 2018); cell refinement: CrysAlis PRO (Rigaku OD, 2018); data reduction: CrysAlis PRO (Rigaku OD, 2018); program(s) used to solve structure: SHELXT (Sheldrick, 2015a); program(s) used to refine structure: SHELXL2018 (Sheldrick, 2015b); molecular graphics: OLEX2 (Dolomanov et al., 2009); software used to prepare material for publication: OLEX2 (Dolomanov et al., 2009).

(E)-N-(2,4-Dimethylphenyl)-2,2,2-trifluoro- $N^{\prime}$-(3-methoxybenzylidene)acetohydrazide

Crystal data

$\mathrm{C}_{18} \mathrm{H}_{17} \mathrm{~F}_{3} \mathrm{~N}_{2} \mathrm{O}_{2}$

$M_{r}=350.33$

Monoclinic, $P 2{ }_{1} / c$

$a=15.0494(3) \AA$

$b=14.2369(3) \AA$

$c=7.9898(2) \AA$

$\beta=99.025(2)^{\circ}$

$V=1690.68(7) \AA^{3}$

$Z=4$

Data collection

Rigaku Oxford Diffraction SuperNova diffractometer with a dual source $(\mathrm{Cu}$ at zero) equipped with an AtlasS2 CCD area detector

Radiation source: micro-focus sealed X-ray tube, SuperNova $(\mathrm{Cu}) \mathrm{X}$-ray Source

Mirror monochromator

Detector resolution: 5.3046 pixels $\mathrm{mm}^{-1}$ $\omega$ scans

Absorption correction: multi-scan

(CrysAlis PRO; Rigaku OD, 2018)

Refinement

Refinement on $F^{2}$

Least-squares matrix: full

$R\left[F^{2}>2 \sigma\left(F^{2}\right)\right]=0.035$

$w R\left(F^{2}\right)=0.096$

$S=0.99$

5945 reflections

230 parameters

0 restraints

Primary atom site location: iterative
$F(000)=728$

$D_{\mathrm{x}}=1.376 \mathrm{Mg} \mathrm{m}^{-3}$

$\mathrm{Cu} K \alpha$ radiation, $\lambda=1.54184 \AA$

Cell parameters from 8396 reflections

$\theta=6.4-73.4^{\circ}$

$\mu=0.97 \mathrm{~mm}^{-1}$

$T=150 \mathrm{~K}$

Block, colourless

$0.2 \times 0.08 \times 0.02 \mathrm{~mm}$

$T_{\min }=0.792, T_{\max }=1.000$

5945 measured reflections

5945 independent reflections

4685 reflections with $I>2 \sigma(I)$

$R_{\text {int }}=0.037$

$\theta_{\max }=73.5^{\circ}, \theta_{\min }=3.0^{\circ}$

$h=-18 \rightarrow 18$

$k=-17 \rightarrow 17$

$l=-9 \rightarrow 9$

Hydrogen site location: inferred from neighbouring sites

$\mathrm{H}$-atom parameters constrained

$w=1 /\left[\sigma^{2}\left(F_{\mathrm{o}}^{2}\right)+(0.0644 P)^{2}\right]$

where $P=\left(F_{\mathrm{o}}{ }^{2}+2 F_{\mathrm{c}}{ }^{2}\right) / 3$

$(\Delta / \sigma)_{\max }<0.001$

$\Delta \rho_{\max }=0.21$ e $\AA^{-3}$

$\Delta \rho_{\min }=-0.23$ e $\AA^{-3}$ 


\section{Special details}

Geometry. All esds (except the esd in the dihedral angle between two 1.s. planes) are estimated using the full covariance matrix. The cell esds are taken into account individually in the estimation of esds in distances, angles and torsion angles; correlations between esds in cell parameters are only used when they are defined by crystal symmetry. An approximate (isotropic) treatment of cell esds is used for estimating esds involving l.s. planes.

Refinement. Refined as a 2-component twin.

The twin ratio is $75: 25$. The twin components are related by a rotation $=179.9993$ deg around the following vectors:

Reciprocal space (hkl): $0.9591-0.0004-0.2832$ Direct space (uvw) : $1.0000-0.0000-0.0000$

More twin information from Crysalis Pro is shown below HKLF 5 merged

RINT ANALYSIS FOR ALL HKLF5 REFLECTIONS Components measured unique redundancy F2/sig(F2) Rint Rsigma — 1,2 4081762026.5813 .100 .0370 .049 RINT ANALYSIS FOR OVERLAPPED REFLECTIONS Components measured unique redundancy F2/sig(F2) Rint Rsigma - 1,2 1553523296.6716 .270 .0340 .042 RINT ANALYSIS FOR ISOLATED REFLECTIONS Component measured unique redundancy F2/sig(F2) Rint Rsigma 0.0610 .103 11263919406.5115 .240 .0350 .04221264319336 .547 .05

Fractional atomic coordinates and isotropic or equivalent isotropic displacement parameters $\left(\AA^{2}\right)$

\begin{tabular}{lllll}
\hline & $x$ & $y$ & $z$ & $U_{\text {iso }} * U_{\text {eq }}$ \\
\hline C1 & $0.79743(10)$ & $0.55247(11)$ & $0.5015(2)$ & $0.0310(3)$ \\
F1A & $0.80312(7)$ & $0.52484(8)$ & $0.66192(12)$ & $0.0429(2)$ \\
F1B & $0.86916(6)$ & $0.52092(7)$ & $0.44165(14)$ & $0.0426(3)$ \\
F1C & $0.80174(6)$ & $0.64552(7)$ & $0.50186(15)$ & $0.0465(3)$ \\
C2 & $0.70649(9)$ & $0.52283(11)$ & $0.39492(18)$ & $0.0269(3)$ \\
O2 & $0.65540(7)$ & $0.58383(8)$ & $0.33280(15)$ & $0.0346(3)$ \\
N3 & $0.68799(8)$ & $0.42978(9)$ & $0.38228(16)$ & $0.0274(3)$ \\
N4 & $0.75575(8)$ & $0.36869(9)$ & $0.45448(16)$ & $0.0275(3)$ \\
C5 & $0.74210(9)$ & $0.28083(11)$ & $0.43262(19)$ & $0.0292(3)$ \\
H5 & 0.687429 & 0.258876 & 0.368883 & $0.035^{*}$ \\
C6 & $0.81146(9)$ & $0.21384(10)$ & $0.50661(19)$ & $0.0279(3)$ \\
C7 & $0.88960(10)$ & $0.24511(11)$ & $0.61040(18)$ & $0.0291(3)$ \\
H7 & 0.898622 & 0.310195 & 0.633233 & $0.035^{*}$ \\
C8 & $0.95351(10)$ & $0.18023(11)$ & $0.6793(2)$ & $0.0325(3)$ \\
O8 & $1.03238(8)$ & $0.20262(9)$ & $0.77993(18)$ & $0.0448(3)$ \\
C9 & $0.94022(11)$ & $0.08438(12)$ & $0.6455(2)$ & $0.0369(4)$ \\
H9 & 0.984103 & 0.040119 & 0.693868 & $0.044^{*}$ \\
C10 & $0.86373(11)$ & $0.05411(12)$ & $0.5422(2)$ & $0.0371(4)$ \\
H10 & 0.855136 & -0.010989 & 0.519015 & $0.045^{*}$ \\
C11 & $0.79887(10)$ & $0.11852(11)$ & $0.4717(2)$ & $0.0328(3)$ \\
H11 & 0.746236 & 0.097521 & 0.399995 & $0.039^{*}$ \\
C12 & $0.59850(9)$ & $0.40011(10)$ & $0.30719(19)$ & $0.0261(3)$ \\
C13 & $0.53748(9)$ & $0.37550(10)$ & $0.41401(19)$ & $0.0268(3)$ \\
C13A & $0.56160(11)$ & $0.37566(12)$ & $0.6041(2)$ & $0.0350(3)$ \\
H13A & 0.600629 & 0.321894 & 0.640011 & $0.052^{*}$ \\
H13B & 0.506618 & 0.371151 & 0.655018 & $0.052^{*}$ \\
H13C & 0.593278 & 0.434026 & 0.640896 & $0.052^{*}$ \\
C14 & $0.45046(9)$ & $0.35210(11)$ & $0.3373(2)$ & $0.0286(3)$ \\
H14 & 0.407817 & 0.333806 & 0.407057 & $0.034^{*}$ \\
& & & &
\end{tabular}




$\begin{array}{lllll}\text { C15 } & 0.42381(9) & 0.35456(10) & 0.1622(2) & 0.0283(3) \\ \text { C15A } & 0.32796(10) & 0.33260(12) & 0.0862(2) & 0.0371(4) \\ \text { H15A } & 0.311125 & 0.271072 & 0.126430 & 0.056^{*} \\ \text { H15C } & 0.322498 & 0.331594 & -0.037665 & 0.056^{*} \\ \text { H15B } & 0.287938 & 0.380841 & 0.120305 & 0.056^{*} \\ \text { C16 } & 0.48731(10) & 0.37919(11) & 0.0605(2) & 0.0309(3) \\ \text { H16 } & 0.470708 & 0.380628 & -0.059150 & 0.037^{*} \\ \text { C17 } & 0.57474(10) & 0.40166(11) & 0.1329(2) & 0.0303(3) \\ \text { H17 } & 0.617961 & 0.417993 & 0.063091 & 0.036^{*} \\ \text { C18 } & 1.05443(11) & 0.29985(13) & 0.7989(3) & 0.0445(4) \\ \text { H18A } & 1.052627 & 0.328445 & 0.686869 & 0.067^{*} \\ \text { H18B } & 1.114964 & 0.306629 & 0.863909 & 0.067^{*} \\ \text { H18C } & 1.010847 & 0.331309 & 0.859057 & 0.067^{*}\end{array}$

Atomic displacement parameters $\left(\AA^{2}\right)$

\begin{tabular}{|c|c|c|c|c|c|c|}
\hline & $U^{11}$ & $U^{22}$ & $U^{33}$ & $U^{12}$ & $U^{13}$ & $U^{23}$ \\
\hline $\mathrm{C} 1$ & $0.0286(7)$ & $0.0266(8)$ & $0.0363(8)$ & $-0.0010(6)$ & $0.0004(6)$ & $0.0005(6)$ \\
\hline F1A & $0.0474(5)$ & $0.0470(6)$ & $0.0305(5)$ & $-0.0026(4)$ & -0.0060 & $0.0000(4)$ \\
\hline F1B & $0.0270(4)$ & $0.0430(6)$ & $0.0587(6)$ & -0.0025 & $0.0091(4)$ & $-0.0025(5)$ \\
\hline F1C & $0.0396(5)$ & $0.0269(5)$ & $0.0667(7)$ & -0.0045 & $-0.0115(5)$ & $-0.0011(5)$ \\
\hline $\mathrm{C} 2$ & $0.0259(6)$ & $0.0274(7)$ & $0.0269(7)$ & $-0.0006(5)$ & $0.0027(5)$ & $0.0003(6)$ \\
\hline $\mathrm{O} 2$ & $0.0336(5)$ & $0.0257(6)$ & $0.0411(6)$ & 0.0028 & $-0.0044(5)$ & $0.0037(5)$ \\
\hline N3 & $0.0234(5)$ & $0.0240(6)$ & $0.0326(7)$ & $0.0016(4)$ & $-0.0020(5)$ & $0.0027(5)$ \\
\hline N4 & $0.0237(5)$ & $0.0266(7)$ & $0.0311(6)$ & $0.0039(5)$ & $0.0005(5)$ & $0.0027(5)$ \\
\hline $\mathrm{C} 5$ & $0.0274(6)$ & $0.0283(8)$ & $0.0305(8)$ & $0.0017(5)$ & $0.0001(5)$ & $-0.0008(6)$ \\
\hline C6 & $0.0287(7)$ & $0.0263(7)$ & $0.0289(7)$ & $0.0024(5)$ & $0.0051(5)$ & $0.0002(6)$ \\
\hline $\mathrm{C} 7$ & $0.0292(7)$ & $0.0235(8)$ & $0.0345(7)$ & $0.0016(5)$ & $0.0042(5)$ & $-0.0001(7)$ \\
\hline $\mathrm{C} 8$ & $0.0272(7)$ & $0.0309(8)$ & $0.0382(8)$ & $0.0014(6)$ & $0.0016(6)$ & $0.0025(6)$ \\
\hline $\mathrm{O} 8$ & $0.0332(6)$ & $0.0319(7)$ & $0.0627(9)$ & $0.0019(5)$ & $-0.0129(5)$ & $0.0040(6)$ \\
\hline C9 & $0.0361(8)$ & $0.0273(8)$ & $0.0465(10)$ & $0.0080(6)$ & $0.0036(7)$ & $0.0063(7)$ \\
\hline $\mathrm{C} 10$ & $0.0409(8)$ & $0.0245(8)$ & $0.0449(9)$ & $0.0020(6)$ & $0.0035(7)$ & $0.0000(7)$ \\
\hline C11 & $0.0333(7)$ & $0.0284(8)$ & $0.0355(8)$ & $0.0001(6)$ & $0.0019(6)$ & $-0.0023(6)$ \\
\hline C12 & $0.0247(6)$ & $0.0218(7)$ & $0.0302(8)$ & $0.0017(5)$ & $-0.0006(5)$ & $0.0007(5)$ \\
\hline $\mathrm{C} 13$ & $0.0293(7)$ & $0.0218(7)$ & $0.0281(7)$ & $0.0025(5)$ & 0.0009 (5) & $0.0017(6)$ \\
\hline C13A & $0.0350(7)$ & $0.0391(9)$ & $0.0294(8)$ & $-0.0005(6)$ & $0.0005(6)$ & $0.0035(7)$ \\
\hline $\mathrm{C} 14$ & $0.0273(6)$ & $0.0249(7)$ & $0.0333(8)$ & -0.0005 & $0.0037(6)$ & $0.0028(6)$ \\
\hline $\mathrm{C} 15$ & $0.0277(7)$ & $0.0209(7)$ & $0.0346(8)$ & $0.0015(5)$ & $-0.0003(6)$ & $-0.0014(6)$ \\
\hline $\mathrm{C} 15 \mathrm{~A}$ & $0.0293(7)$ & $0.0371(9)$ & $0.0422(9)$ & -0.0019 (6) & $-0.0030(6)$ & $-0.0052(7)$ \\
\hline $\mathrm{C} 16$ & $0.0326(7)$ & $0.0314(8)$ & $0.0269(7)$ & $0.0011(6)$ & $-0.0010(6)$ & $-0.0005(6)$ \\
\hline $\mathrm{C} 17$ & $0.0296(7)$ & $0.0310(8)$ & $0.0300(8)$ & $0.0003(6)$ & $0.0036(6)$ & $0.0027(6)$ \\
\hline $\mathrm{C} 18$ & $0.0346(8)$ & $0.0351(10)$ & $0.0592(12)$ & $-0.0045(7)$ & $-0.0067(8)$ & $0.0017(8)$ \\
\hline
\end{tabular}

Geometric parameters $\left(A,{ }^{o}\right)$

\begin{tabular}{llll}
\hline $\mathrm{C} 1-\mathrm{F} 1 \mathrm{~A}$ & $1.3303(19)$ & $\mathrm{C} 11-\mathrm{H} 11$ & 0.9500 \\
$\mathrm{C} 1-\mathrm{F} 1 \mathrm{~B}$ & $1.3260(18)$ & $\mathrm{C} 12-\mathrm{C} 13$ & $1.393(2)$ \\
$\mathrm{C} 1-\mathrm{F} 1 \mathrm{C}$ & $1.3262(18)$ & $\mathrm{C} 12-\mathrm{C} 17$ & $1.382(2)$
\end{tabular}




\begin{tabular}{|c|c|c|c|}
\hline $\mathrm{C} 1-\mathrm{C} 2$ & $1.5527(19)$ & $\mathrm{C} 13-\mathrm{C} 13 \mathrm{~A}$ & $1.505(2)$ \\
\hline $\mathrm{C} 2-\mathrm{O} 2$ & $1.2133(18)$ & $\mathrm{C} 13-\mathrm{C} 14$ & $1.396(2)$ \\
\hline $\mathrm{C} 2-\mathrm{N} 3$ & $1.354(2)$ & $\mathrm{C} 13 \mathrm{~A}-\mathrm{H} 13 \mathrm{~A}$ & 0.9800 \\
\hline $\mathrm{N} 3-\mathrm{N} 4$ & $1.3944(16)$ & $\mathrm{C} 13 \mathrm{~A}-\mathrm{H} 13 \mathrm{~B}$ & 0.9800 \\
\hline $\mathrm{N} 3-\mathrm{C} 12$ & $1.4487(17)$ & $\mathrm{C} 13 \mathrm{~A}-\mathrm{H} 13 \mathrm{C}$ & 0.9800 \\
\hline $\mathrm{N} 4-\mathrm{C} 5$ & $1.275(2)$ & $\mathrm{C} 14-\mathrm{H} 14$ & 0.9500 \\
\hline $\mathrm{C} 5-\mathrm{H} 5$ & 0.9500 & $\mathrm{C} 14-\mathrm{C} 15$ & $1.394(2)$ \\
\hline $\mathrm{C} 5-\mathrm{C} 6$ & $1.468(2)$ & $\mathrm{C} 15-\mathrm{C} 15 \mathrm{~A}$ & $1.5076(19)$ \\
\hline $\mathrm{C} 6-\mathrm{C} 7$ & $1.401(2)$ & $\mathrm{C} 15-\mathrm{C} 16$ & $1.393(2)$ \\
\hline $\mathrm{C} 6-\mathrm{C} 11$ & $1.392(2)$ & $\mathrm{C} 15 \mathrm{~A}-\mathrm{H} 15 \mathrm{~A}$ & 0.9800 \\
\hline $\mathrm{C} 7-\mathrm{H} 7$ & 0.9500 & $\mathrm{C} 15 \mathrm{~A}-\mathrm{H} 15 \mathrm{C}$ & 0.9800 \\
\hline $\mathrm{C} 7-\mathrm{C} 8$ & $1.384(2)$ & $\mathrm{C} 15 \mathrm{~A}-\mathrm{H} 15 \mathrm{~B}$ & 0.9800 \\
\hline $\mathrm{C} 8-\mathrm{O} 8$ & $1.3629(19)$ & $\mathrm{C} 16-\mathrm{H} 16$ & 0.9500 \\
\hline $\mathrm{C} 8-\mathrm{C} 9$ & $1.399(2)$ & $\mathrm{C} 16-\mathrm{C} 17$ & $1.389(2)$ \\
\hline $\mathrm{O} 8-\mathrm{C} 18$ & $1.426(2)$ & $\mathrm{C} 17-\mathrm{H} 17$ & 0.9500 \\
\hline $\mathrm{C} 9-\mathrm{H} 9$ & 0.9500 & $\mathrm{C} 18-\mathrm{H} 18 \mathrm{~A}$ & 0.9800 \\
\hline $\mathrm{C} 9-\mathrm{C} 10$ & $1.376(2)$ & $\mathrm{C} 18-\mathrm{H} 18 \mathrm{~B}$ & 0.9800 \\
\hline $\mathrm{C} 10-\mathrm{H} 10$ & 0.9500 & $\mathrm{C} 18-\mathrm{H} 18 \mathrm{C}$ & 0.9800 \\
\hline $\mathrm{C} 10-\mathrm{C} 11$ & $1.393(2)$ & & \\
\hline $\mathrm{F} 1 \mathrm{~A}-\mathrm{C} 1-\mathrm{C} 2$ & $111.48(12)$ & $\mathrm{C} 17-\mathrm{C} 12-\mathrm{N} 3$ & $119.30(13)$ \\
\hline $\mathrm{F} 1 \mathrm{~B}-\mathrm{C} 1-\mathrm{F} 1 \mathrm{~A}$ & $108.32(12)$ & $\mathrm{C} 17-\mathrm{C} 12-\mathrm{C} 13$ & $122.00(13)$ \\
\hline $\mathrm{F} 1 \mathrm{~B}-\mathrm{C} 1-\mathrm{F} 1 \mathrm{C}$ & $107.26(12)$ & $\mathrm{C} 12-\mathrm{C} 13-\mathrm{C} 13 \mathrm{~A}$ & $122.68(13)$ \\
\hline $\mathrm{F} 1 \mathrm{~B}-\mathrm{C} 1-\mathrm{C} 2$ & $114.04(13)$ & $\mathrm{C} 12-\mathrm{C} 13-\mathrm{C} 14$ & $117.01(13)$ \\
\hline $\mathrm{F} 1 \mathrm{C}-\mathrm{C} 1-\mathrm{F} 1 \mathrm{~A}$ & $107.32(13)$ & $\mathrm{C} 14-\mathrm{C} 13-\mathrm{C} 13 \mathrm{~A}$ & $120.30(14)$ \\
\hline $\mathrm{F} 1 \mathrm{C}-\mathrm{C} 1-\mathrm{C} 2$ & $108.13(12)$ & $\mathrm{C} 13-\mathrm{C} 13 \mathrm{~A}-\mathrm{H} 13 \mathrm{~A}$ & 109.5 \\
\hline $\mathrm{O} 2-\mathrm{C} 2-\mathrm{C} 1$ & $118.51(13)$ & $\mathrm{C} 13-\mathrm{C} 13 \mathrm{~A}-\mathrm{H} 13 \mathrm{~B}$ & 109.5 \\
\hline $\mathrm{O} 2-\mathrm{C} 2-\mathrm{N} 3$ & $124.06(13)$ & $\mathrm{C} 13-\mathrm{C} 13 \mathrm{~A}-\mathrm{H} 13 \mathrm{C}$ & 109.5 \\
\hline $\mathrm{N} 3-\mathrm{C} 2-\mathrm{C} 1$ & $117.39(12)$ & $\mathrm{H} 13 \mathrm{~A}-\mathrm{C} 13 \mathrm{~A}-\mathrm{H} 13 \mathrm{~B}$ & 109.5 \\
\hline $\mathrm{C} 2-\mathrm{N} 3-\mathrm{N} 4$ & $116.80(11)$ & $\mathrm{H} 13 \mathrm{~A}-\mathrm{C} 13 \mathrm{~A}-\mathrm{H} 13 \mathrm{C}$ & 109.5 \\
\hline $\mathrm{C} 2-\mathrm{N} 3-\mathrm{C} 12$ & $118.88(11)$ & $\mathrm{H} 13 \mathrm{~B}-\mathrm{C} 13 \mathrm{~A}-\mathrm{H} 13 \mathrm{C}$ & 109.5 \\
\hline $\mathrm{N} 4-\mathrm{N} 3-\mathrm{C} 12$ & $124.16(12)$ & $\mathrm{C} 13-\mathrm{C} 14-\mathrm{H} 14$ & 118.8 \\
\hline $\mathrm{C} 5-\mathrm{N} 4-\mathrm{N} 3$ & $117.62(12)$ & $\mathrm{C} 15-\mathrm{C} 14-\mathrm{C} 13$ & $122.48(13)$ \\
\hline $\mathrm{N} 4-\mathrm{C} 5-\mathrm{H} 5$ & 120.2 & $\mathrm{C} 15-\mathrm{C} 14-\mathrm{H} 14$ & 118.8 \\
\hline $\mathrm{N} 4-\mathrm{C} 5-\mathrm{C} 6$ & $119.54(13)$ & $\mathrm{C} 14-\mathrm{C} 15-\mathrm{C} 15 \mathrm{~A}$ & $120.39(14)$ \\
\hline $\mathrm{C} 6-\mathrm{C} 5-\mathrm{H} 5$ & 120.2 & $\mathrm{C} 16-\mathrm{C} 15-\mathrm{C} 14$ & $118.42(13)$ \\
\hline $\mathrm{C} 7-\mathrm{C} 6-\mathrm{C} 5$ & $120.64(13)$ & $\mathrm{C} 16-\mathrm{C} 15-\mathrm{C} 15 \mathrm{~A}$ & $121.18(14)$ \\
\hline $\mathrm{C} 11-\mathrm{C} 6-\mathrm{C} 5$ & $119.12(13)$ & $\mathrm{C} 15-\mathrm{C} 15 \mathrm{~A}-\mathrm{H} 15 \mathrm{~A}$ & 109.5 \\
\hline $\mathrm{C} 11-\mathrm{C} 6-\mathrm{C} 7$ & 120.24 (14) & $\mathrm{C} 15-\mathrm{C} 15 \mathrm{~A}-\mathrm{H} 15 \mathrm{C}$ & 109.5 \\
\hline $\mathrm{C} 6-\mathrm{C} 7-\mathrm{H} 7$ & 120.3 & $\mathrm{C} 15-\mathrm{C} 15 \mathrm{~A}-\mathrm{H} 15 \mathrm{~B}$ & 109.5 \\
\hline $\mathrm{C} 8-\mathrm{C} 7-\mathrm{C} 6$ & $119.33(14)$ & $\mathrm{H} 15 \mathrm{~A}-\mathrm{C} 15 \mathrm{~A}-\mathrm{H} 15 \mathrm{C}$ & 109.5 \\
\hline $\mathrm{C} 8-\mathrm{C} 7-\mathrm{H} 7$ & 120.3 & $\mathrm{H} 15 \mathrm{~A}-\mathrm{C} 15 \mathrm{~A}-\mathrm{H} 15 \mathrm{~B}$ & 109.5 \\
\hline $\mathrm{C} 7-\mathrm{C} 8-\mathrm{C} 9$ & $120.31(14)$ & $\mathrm{H} 15 \mathrm{C}-\mathrm{C} 15 \mathrm{~A}-\mathrm{H} 15 \mathrm{~B}$ & 109.5 \\
\hline $\mathrm{O} 8-\mathrm{C} 8-\mathrm{C} 7$ & $124.41(15)$ & $\mathrm{C} 15-\mathrm{C} 16-\mathrm{H} 16$ & 119.8 \\
\hline $\mathrm{O} 8-\mathrm{C} 8-\mathrm{C} 9$ & $115.27(14)$ & $\mathrm{C} 17-\mathrm{C} 16-\mathrm{C} 15$ & $120.46(14)$ \\
\hline $\mathrm{C} 8-\mathrm{O} 8-\mathrm{C} 18$ & $117.16(13)$ & $\mathrm{C} 17-\mathrm{C} 16-\mathrm{H} 16$ & 119.8 \\
\hline $\mathrm{C} 8-\mathrm{C} 9-\mathrm{H} 9$ & 119.9 & $\mathrm{C} 12-\mathrm{C} 17-\mathrm{C} 16$ & $119.62(14)$ \\
\hline $\mathrm{C} 10-\mathrm{C} 9-\mathrm{C} 8$ & $120.13(14)$ & $\mathrm{C} 12-\mathrm{C} 17-\mathrm{H} 17$ & 120.2 \\
\hline
\end{tabular}


supporting information

$\begin{array}{lllr}\mathrm{C} 10-\mathrm{C} 9-\mathrm{H} 9 & 119.9 & \mathrm{C} 16-\mathrm{C} 17-\mathrm{H} 17 & 120.2 \\ \mathrm{C} 9-\mathrm{C} 10-\mathrm{H} 10 & 119.9 & \mathrm{O} 8-\mathrm{C} 18-\mathrm{H} 18 \mathrm{~A} & 109.5 \\ \mathrm{C} 9-\mathrm{C} 10-\mathrm{C} 11 & 120.25(15) & \mathrm{O} 8-\mathrm{C} 18-\mathrm{H} 18 \mathrm{~B} & 109.5 \\ \mathrm{C} 11-\mathrm{C} 10-\mathrm{H} 10 & 119.9 & \mathrm{O} 8-\mathrm{C} 18-\mathrm{H} 18 \mathrm{C} & 109.5 \\ \mathrm{C} 6-\mathrm{C} 11-\mathrm{C} 10 & 119.74(14) & \mathrm{H} 18 \mathrm{~A}-\mathrm{C} 18-\mathrm{H} 18 \mathrm{~B} & 109.5 \\ \mathrm{C} 6-\mathrm{C} 11-\mathrm{H} 11 & 120.1 & \mathrm{H} 18 \mathrm{~A}-\mathrm{C} 18-\mathrm{H} 18 \mathrm{C} & 109.5 \\ \mathrm{C} 10-\mathrm{C} 11-\mathrm{H} 11 & 120.1 & \mathrm{H} 18 \mathrm{~B}-\mathrm{C} 18-\mathrm{H} 18 \mathrm{C} & 109.5 \\ \mathrm{C} 13-\mathrm{C} 12-\mathrm{N} 3 & 118.62(13) & & \end{array}$

